\title{
Land use change and carbon fluxes in East Africa quantified using earth observation data and field measurements
}

\author{
M. PFEIFER ${ }^{1,2 *}$, P.J. PLATTS ${ }^{2,3}$, N.D. BURGESS $S^{3,4,5}$, R.D. SWETNAM ${ }^{6}$, S. WILLCOCK ${ }^{7}$, \\ S. L. LEWIS ${ }^{7}$ AND R. MARCHANT ${ }^{2}$ \\ ${ }^{1}$ Faculty of Natural Sciences, Imperial College of Science, Technology and Medicine, Silwood Park Campus, Ascot, Buckhurst Road, London SL5 \\ $7 P Y$, UK, ${ }^{2}$ York Institute for Tropical Ecosystem Dynamics, Environment Department, University of York, Heslington, York YO10 5DD, UK, \\ ${ }^{3}$ Conservation Science Group, Department of Zoology, University of Cambridge, Domning Street, Cambridge CB2 3EF, UK, ${ }^{4}$ Centre for \\ Macroecology, Evolution and Climate, Department of Biology, University of Copenhagen, Denmark, ${ }^{5}$ WWF-US Conservation Science Programme, \\ Washington DC, USA, ${ }^{6}$ Department of Geography, Staffordshire University, Leek Road, Stoke-on-Trent ST4 2DF, UK, and ${ }^{7}$ School of \\ Geography, University of Leeds, Leeds LS2 97T, UK
}

Date submitted: 23 March 2012; Date accepted: 27 September 2012; First published online: 10 December 2012

\section{SUMMARY}

Carbon-based forest conservation requires the establishment of 'reference emission levels' against which to measure a country or region's progress in reducing their carbon emissions. In East Africa, landscape-scale estimates of carbon fluxes are uncertain and factors such as deforestation poorly resolved due to a lack of data. In this study, trends in vegetation cover and carbon for East Africa were quantified using moderateresolution imaging spectroradiometer (MODIS) land cover grids from 2002 to 2008 (500-m spatial resolution), in combination with a regional carbon look-up table. The inclusion of data on rainfall and the distribution of protected areas helped to gauge impacts on vegetation burning (assessed using 1-km spatial resolution MODIS active fire data) and biome trends. Between 2002 and 2008, the spatial extents of forests, woodlands and scrublands decreased considerably and East Africa experienced a net carbon loss of 494 megatonnes (Mt). Most countries in the area were sources of carbon emissions, except for Tanzania and Malawi, where the areal increase of savannah and woodlands counterbalanced carbon emissions from deforestation. Both Malawi and Tanzania contain large areas of planted forest. Vegetation burning was correlated with rainfall (forest only) and differed depending on land management. Freely available global earth observation products have provided ways to achieve rapid assessment and monitoring of carbon change hotspots at the landscape scale.

Keymords: earth observation products, carbon stocks, carbon trends, fire regimes, $M O D I S$, look-up table, savannah

\section{INTRODUCTION}

The management and conservation of tropical carbon stores by channelling funds from developed to developing countries is a promising tool for reducing greenhouse gas emissions (Laurance 2007). Africa contains 13\% of global terrestrial carbon (in living plants and soil), and emissions resulting from land-use change account for nearly $20 \%$ of the total for the tropics (Williams et al. 2007). Forest and woodland conversion is primarily linked to subsistence farming and fuel extraction (Fisher et al. 2011), while carbon stocks are also threatened by logging, mining and the development of commercial agriculture.

Carbon-based conservation using the concept of payment for ecosystem services, for example via the United Nations Programme on Reducing Emissions from Deforestation and Degradation in Developing Countries (REDD+) (Ebeling \& Yasue 2008), faces a number of challenges (Fisher et al. 2011). A key requirement in a workable REDD+ scheme is the establishment of 'reference [emission] levels' (RLs) against which to measure a country or region's progress in reducing their carbon emissions and increasing the carbon store. Griscom et al. (2009) reviewed different methods proposed to determine national baseline emissions, concluding that for REDD payments to successfully function as incentives to reduce emissions, they should be closely linked in quantity to actual emissions avoided against a credible historicallyderived baseline with limited adjustments.

Field measurements of forest emissions (based on forest changes) are often used in order to establish RLs. Multitemporal forest inventories are combined with stand biomass density datasets to subsequently calculate landscape estimates of above-ground biomass and their changes over time (NávarChaidez 2011). However, they are very expensive and errors may be introduced by subjective sampling, especially across large spatial scales (Yokkoz et al. 2001), when avoiding remote, difficult to access or politically unstable areas for measuring forest distribution and biomass on the ground.

\footnotetext{
*Correspondence: Dr Marion Pfeifer e-mail: marion.pfeifer@googlemail.com

The online version of this article is published within an Open Access environment subject to the conditions of the Creative Commons Attribution-NonCommercial-ShareAlike licence <http://creativecommons.org/licenses/by-nc-sa/2.5/>. The written permission of Cambridge University Press must be obtained for commercial re-use.
} 
Alternatively, high-spatial resolution passive satellite data have been employed to derive estimates of forest cover, biomass and carbon storage at landscape and even national scales. A set of ground measurements is upscaled from plot level using remotely sensed spectral reflectances (Wulder et al. 2008). Whilst providing highly likely measures for local scales, their application at landscape level is limited by the need to obtain cloud-free images at sufficient temporal resolution, and to account for errors introduced during image mosaicking (inevitable, because of the reduced spatial coverage of each individual satellite scene). Furthermore, high computer processing capacity is required for change detection analyses, and costs associated with obtaining and processing these images currently are prohibitive for many countries. Using active sensor data (such as airborne light detection and ranging [LiDAR]) to directly estimate biomass from forest structure estimates (Zhao et al. 2009) requires sophisticated technical equipment, which is very expensive (Englhart et al. 2011) and is hampered by uncertainties introduced through instrument and flight specifics (Disney et al. 2010). Furthermore, synthetic aperture radar data, while weather and daylight independent, show saturation at high biomass levels (Lucas et al. 2007).

In East Africa and elsewhere, landscape-scale estimates of carbon stock are uncertain and determinants of flux, such as deforestation and degradation processes, poorly resolved (Williams et al. 2007; Návar-Chaidez 2010; Pfeifer et al. 2012a). The moist tropical forests (mainly in Eastern Congo, Rwanda and Burundi, the Eastern Arc Mountains and coastal areas) are recognized as important carbon sinks (Lewis et al. 2009). However, these forested areas are small relative to other woody biomes, which cover over half of East Africa's terrestrial surface, such as Miombo and open AcaciaCommiphora woodlands (forest cover only $6 \%$ ), representing a heterogeneous mosaic of tree densities, tree heights and above-ground biomass stocks (Burgess et al. 2004). Analyses of savannah biomes in South Africa reveal highly transient systems (Bond et al. 2005) whose extents and structures reflect complex interactions between fire regimes, rainfall, human activities and herbivore pressure (Bucini \& Hanan 2007).

Efficient and reliable assessment of land cover dynamics is essential for adaptive management in the face of rapid socioeconomic and environmental change. In recent decades, economic development and increasing population pressure have accelerated rates of deforestation and degradation in East Africa (Hall et al. 2009; Ahrends et al. 2010; Godoy et al. 2011; Pfeifer et al. 2012a). Population changes may also have increased burning frequencies relative to historical regimes (Keeley et al. 1999), possibly impacting carbon fluxes. Carbon balances for woody vegetation are expected to change further, as demands for land and wood-based fuel continue to increase (Brncic et al. 2007). This may be counterbalanced by potential $\mathrm{CO}_{2}$ and atmospheric nitrogen fertilization effects (Kgope et al. 2010), and the loss of large mammals causing habitat shifts from grassland to bushland (Holdo et al. 2009).
Here, we describe an 'historical' approach to establishing baselines for canopy cover change and associated aboveground carbon flux at a landscape scale, whereby average historical deforestation rates are estimated from earth observation derived land cover maps. We focus on changes in forest and woody biomes, relative to cultivated land, to assess the region's carbon stocks and fluxes and test for vegetation changes in relation to fire, precipitation and land management. We present our approach as a rapid assessment tool for land cover and carbon trends in East Africa, making use of freely available land cover, precipitation and fire maps. A major advantage of our approach, which should be seen as complementary to ongoing small-scale carbon quantification projects and groundbased monitoring (described in Harper et al. 2007 and Godoy et al. 2011; discussed in Gibbs et al. 2007), is its ability to overcome the lack of consistent field-based data in East Africa, which has hitherto hampered large-scale detection of carbon change hotspots.

\section{METHODS}

\section{Study area}

Our study area is $3882887 \mathrm{~km}^{2}$ (N6, S15, W27.5, E42.5), covering fully the countries of Uganda, Kenya, Tanzania, Rwanda and Burundi, and partially covering neighbouring Somalia, Ethiopia, South Sudan, Congo, Zambia, Malawi and Mozambique (Fig. 1). The region encompasses a range of biomes, including lowland, coastal and mountain forests, open and closed woodlands, mangroves along the coast and open dry xeric bushland in the north.

\section{Estimating carbon flux from remotely-sensed biome shifts}

We computed changes in the spatial coverage of East African biomes between 2002 and 2008. Biome-specific above-ground live carbon stocks, per unit area, were estimated using an East Africa specific look-up table (Willcock et al. 2012). These ground-based inventory data represent weighted medians and 95\% bootstrapped confidence intervals (CIs), derived from a wide range of literature sources (Table 1). They include data from across a range of levels of anthropogenic disturbance within biomes.

Vegetation cover data were extracted from $500 \mathrm{~m} \times$ $500 \mathrm{~m}$ spatial resolution MODIS land cover grids using the International Geosphere Biosphere Programme (IGBP) classification of biomes (Cohen et al. 2006). To reduce uncertainties resulting from biome confusions (Hodgens 2002, Friedl et al. 2010), we reclassified IGBP vegetation into forests (evergreen broadleaved forest), woodlands (deciduous broadleaf forests), savannahs (woody savannah and savannah), scrublands (open and closed scrublands), grasslands, croplands (cropland and cropland/natural vegetation mosaics), and urban areas. Varying classification accuracy is a quantified problem in land cover products and overall accuracy of the MODIS IGBP land cover scheme is 
(a) East Africa, biome coverage in 2008

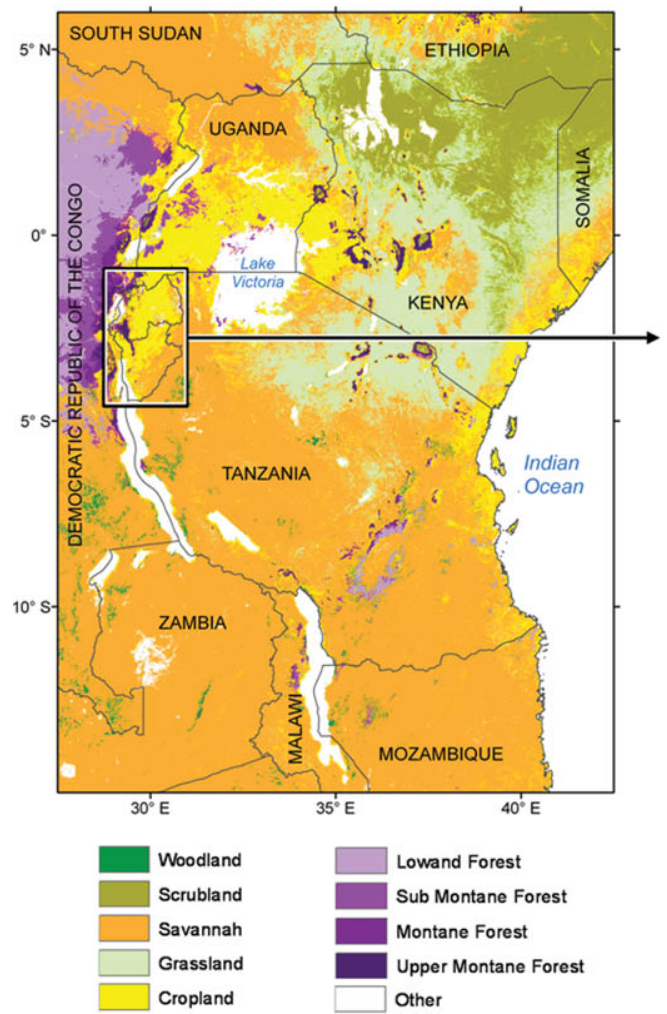

Rwanda and Burundi, change between 2002-2008

(b) Biome transitions

(c) Change in carbon (tonnes/ha)

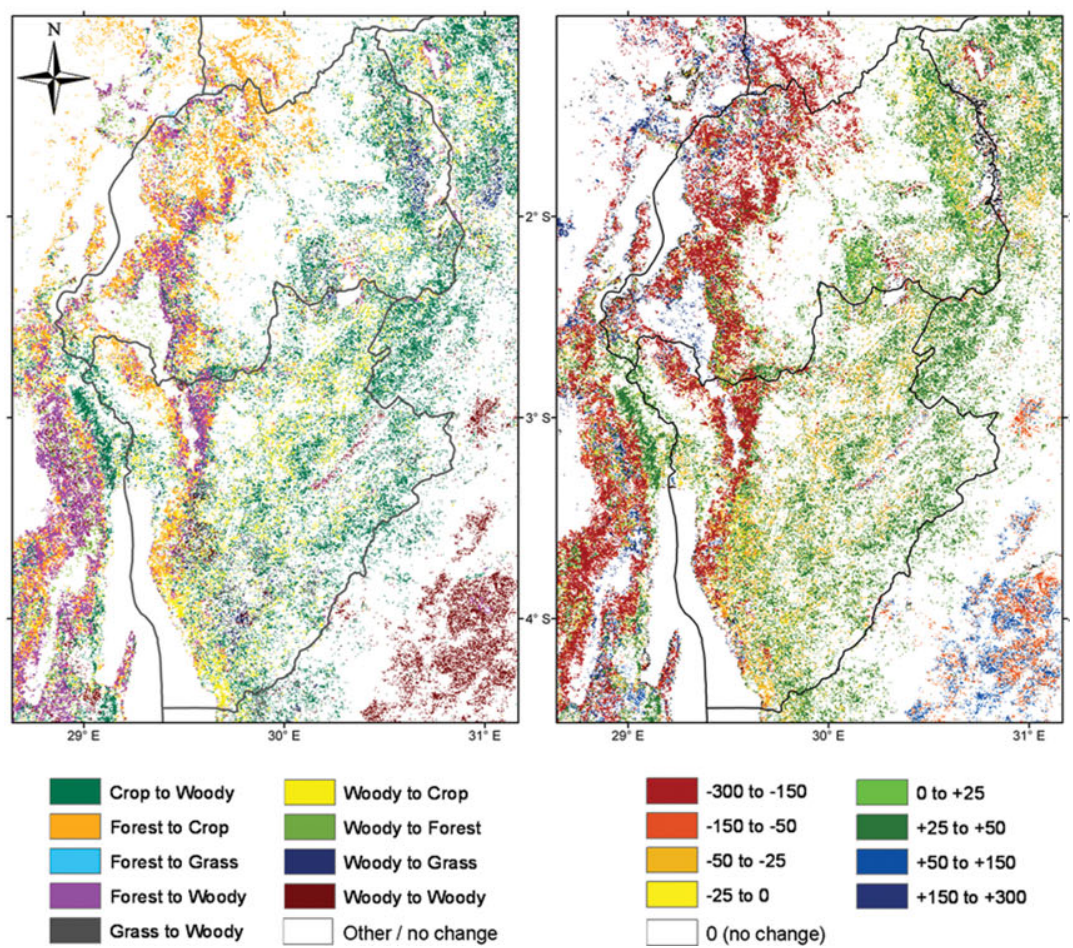

Figure 1 Land cover change and carbon fluxes in East Africa. (a) Woody biomes together represented $>50 \%$ of the terrestrial surface in 2008. (b) Major biome transitions between 2002 and 2008 in Rwanda, Burundi and eastern DRC. (c) Resultant changes in above ground carbon stock.

Table 1 Estimates for aboveground live carbon in biomes of East Africa (weighted median; 95\% confidence intervals) extracted from a look-up table containing aboveground measured median carbon storage values (weighted) from 71 published and six unpublished data sources for the Food and Agriculture Organization of the United Nations (FAO) land-use categories (Willcock et al. 2012). asl = above sea level.

\begin{tabular}{llll}
\hline \hline Land use category & & Biome & Median carbon t ha ${ }^{-1}$ [95\% CI] \\
\hline Forest & Lowland $(<1000 \mathrm{~m}$ asl $)$ & Forest & $206.7[194.9,219.5]$ \\
& Submontane $(1000-1500 \mathrm{~m}$ asl $)$ & Forest & $283.2[252.1,328.9]$ \\
& Montane $(1500-2000 \mathrm{~m}$ asl $)$ & Forest & $228.3[189.6,286.1]$ \\
Woody & Upper montane $(>2000 \mathrm{~m}$ asl) & Forest & $201.7[72.7,331.7]$ \\
& Closed woodland & Woodland & $103.1[69.6,126.3]$ \\
& Open woodland & Savannah & $46.0[37.7,55.3]$ \\
Agriculture & Bushland & Scrubland & $61.6[30.6,107.2]$ \\
Grassland & & Cropland & $2.8[1.6,4.8]$ \\
\hline \hline
\end{tabular}

c. 75\% (Friedl et al. 2010; Appendix 1, see supplementary material at Journals.cambridge.org/ENC). Because of the consistent generation of these products over time, relative pixel changes per time period will be accurate even if absolute land cover classes are not.

\section{Relationship between fire and biomes}

We compared biome burning probabilities with the probability of biome transition. Information on fire locations was extracted from MODIS Active Fire data (Giglio et al. 2003), provided with 1-km geolocation accuracy by NASA/University of Maryland (2002). We concentrated on fire locations with a reported accuracy $\geq 50 \%$, accepting that this may result in an underestimation of fire frequencies. Fire data were converted to grids, indicating whether a pixel was burned or not in a given year. Note that active fire estimates tend to underestimate the frequency and distribution of smaller short-lived fires, which may flare up and burn out before they are detected. For consistency with the fire information, biome grids were reprojected to $1-\mathrm{km}$ resolution using ArcGIS v9.3. 
Table 2 Aboveground carbon flows based on biome shifts between 2002 and 2008. Carbon values in mega tonnes (Mt) with 95\% confidence intervals (CI). See also Table 1. Grassland and cropland changes are uncertain due to probable spectral confusion between certain crops and grassland (see text for more details). ${ }^{\mathrm{a}}$ Forest carbon varies with altitude, peaking for submontane forests (1000-1500 $\mathrm{m}$ above mean sea level).

\begin{tabular}{|c|c|c|c|c|}
\hline \multirow[b]{2}{*}{ Biome } & \multicolumn{2}{|c|}{ Cover in East Africa $\left(\mathrm{km}^{2}\right)$} & \multicolumn{2}{|c|}{ Estimated carbon stock (Mt [95\% CI]) } \\
\hline & Baseline 2002 & Change 2002-2008 & Baseline 2002 & Change 2002-2008 \\
\hline$\overline{\text { Forest }^{\mathrm{a}}}$ & 250437 & -12810 & $5703[4869,6699]$ & $-288[-383,-206]$ \\
\hline Woodland & 42787 & -6775 & $441[298,541]$ & $-70[-86,-47]$ \\
\hline Scrub & 398713 & -77478 & $2455[1222,4276]$ & $-477[-831,-237]$ \\
\hline Savannah & 1870762 & +49822 & $8605[7057,10341]$ & $+229[188,275]$ \\
\hline Grassland & 360825 & +65477 & $644[56,650]$ & $+117[10,118]$ \\
\hline Cropland & 327687 & -17457 & $90[53,157]$ & $-4.8[-8.4,-2.8]$ \\
\hline Total & 3251211 & - & $17939[13554,22663]$ & $-494[-914,-295]$ \\
\hline
\end{tabular}

\section{Assessing rainfall as a driver of change}

Precipitation varies considerably in amount and seasonality across East Africa (Nicholson 2000; Schreck \& Semazzi 2004), impacting on vegetation cover and burning (Archibald et al. 2010 demonstrated this for Southern Africa). WorldClim interpolated climatology (covering more than 30 years of measurements, see http://www.worldclim.org/; Hijmans et al. 2005) was used to compute long-term mean annual precipitation (MAP) at 1-km spatial resolution for each biome based on biome coverage in 2008, aiming to determine the precipitation niche of each biome.

In addition, we used 10-day rainfall estimates (African Rainfall Estimation Algorithm, RFE version 2.0; National Oceanic and Atmospheric Administration's Climate Prediction Centre, see http://www.cpc.ncep.noaa. gov/products/fews/RFE2.0_tech.pdf) to calculate changes in interannual precipitation (IAP). The RFE algorithm combines satellite information via maximum likelihood estimation, while global telecommunication system station data (rain gauge totals from more than 1000 stations) are used to remove bias. RFE products for the years 2001 to 2009 were converted to annual estimates and reclassified into 100$\mathrm{mm}$ bins. These data are currently the best available tool for modelling interannual variation in vegetation and fire patterns, although applicability is limited in highly heterogeneous landscapes (such as mountainous areas) due to their relatively coarse spatial resolution (8-km grids).

\section{Assessing changes in relation to land management}

Biome cover trends (2002-2008), biome burning probabilities and their links to precipitation were analysed separately for each land management scheme. The World Database on Protected Areas (IUCN [International Union for the Conservation of Nature] \& UNEP-WCMC [United Nations Environment Programme World Conservation Monitoring Centre] 2010) was used to define the boundaries of five land management schemes that differ in their protection status and effectiveness (Caro et al. 2009; Pfeifer et al. 2012a): national parks, nature reserves, forest reserves (government, district and village managed forest reserves), game parks (game reserves, game controlled areas and wildlife management areas) and unprotected areas (village, private or open access management). Nature reserves comprise $0.3 \%$ of the study area, forest reserves $4.0 \%$, national parks $4.2 \%$ and game parks $7.2 \%$. The majority of the study region $(82.0 \%$, $\left.3.2 \times 10^{6} \mathrm{~km}^{2}\right)$ is not protected. The remaining land area $\left(89306 \mathrm{~km}^{2}\right)$ is designated under other protection categories (such as national reserves).

We used ANOVA with multi-comparison post-hoc Tukey HSD tests to test for significant differences between biomes and between land management types with regard to the percentage of woody vegetation burning. Spatial analyses were carried out using ArcGIS v9.3 software (http://www.esri.com/). Statistical models and graphics were computed using the $\mathrm{R}$ v2.11.1 statistical software environment (http://www.r-project.org/).

\section{RESULTS}

\section{Biome distribution and cover trends}

Based on vegetation cover in 2008 (Fig. 1a), savannah biomes represented $58 \%$ of the terrestrial surface of the East African region. Grasslands $(12.9 \%)$, scrublands $(9.7 \%)$, croplands $(9.4 \%)$, forests $(7.2 \%)$ and woodlands $(1.1 \%)$ were much less frequent. Urban areas made up $0.1 \%$ of the land surface (Table 2). Between 2002 and 2008 forest cover decreased in area by $5.1 \%$, woodland cover decreased by $15.8 \%$ and scrubland cover decreased by $19.4 \%$; cover of savannah biomes increased by $2.7 \%$ (Table 2). Around $6 \%$ of forest pixels changed to savannah and $5.2 \%$ changed to cropland (but only $0.2 \%$ to grassland); $5.2 \%$ of savannah became grassland and $4.2 \%$ cropland (Table 3 ).

\section{Changes in above-ground live carbon between 2002 and 2008}

There was a net loss of above-ground carbon of $494 \mathrm{Mt}$ (CI 95\%: -295 to -914 ) due to biome shifts in the study area between 2002 and 2008. Deforestation emissions amounted to $288 \mathrm{Mt}$. Decreases in scrubland and woodlands resulted in carbon losses of $477 \mathrm{Mt}$ and $70 \mathrm{Mt}$, respectively. This 
Table 3 Matrix showing pixel-based land-cover transitions in the study area based on MODIS biome maps in 2002 and 2008. *High probability for stasis of land cover between 2002 and 2008.

\begin{tabular}{llllllllll}
\hline \hline Biome & Water & Forest & Woodland & Scrubland & Savannah & Grassland & Cropland & Urban & Others \\
\hline Water & 0.990 & 0.000 & 0.000 & 0.000 & 0.000 & 0.000 & 0.000 & 0.000 & 0.008 \\
Forest & 0.000 & $0.870^{*}$ & 0.009 & 0.002 & 0.058 & 0.002 & 0.052 & 0.000 & 0.006 \\
Woodland & 0.000 & 0.025 & $0.254^{*}$ & 0.001 & 0.672 & 0.003 & 0.031 & 0.000 & 0.015 \\
Scrubland & 0.000 & 0.000 & 0.000 & $0.700^{*}$ & 0.032 & 0.253 & 0.008 & 0.000 & 0.006 \\
Savannah & 0.000 & 0.005 & 0.011 & 0.003 & $0.883^{*}$ & 0.052 & 0.042 & 0.000 & 0.004 \\
Grassland & 0.000 & 0.002 & 0.001 & 0.076 & 0.267 & $0.576^{*}$ & 0.075 & 0.000 & 0.002 \\
Cropland & 0.000 & 0.019 & 0.004 & 0.003 & 0.342 & 0.060 & $0.567^{*}$ & 0.000 & 0.005 \\
Urban & 0.000 & 0.000 & 0.000 & 0.000 & 0.000 & 0.000 & 0.000 & $0.999^{*}$ & 0.001 \\
Others & 0.021 & 0.044 & 0.008 & 0.178 & 0.081 & 0.009 & 0.023 & 0.000 & $0.636^{*}$ \\
\hline \hline
\end{tabular}

Table 4 Above ground carbon in 2008 (megatonnes, Mt), detailed by country. Reference emission levels (RLs, change in median C

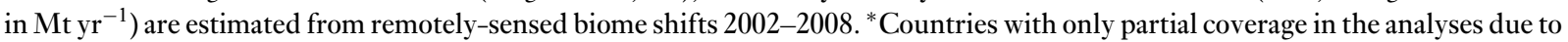
study area definition. BDI = Burundi; DRC $=$ Congo; $\mathrm{ETH}=$ Ethiopia; $\mathrm{KEN}=$ Kenya; MOZ = Mozambique; MWI = Malawi; $\mathrm{RWA}=$ Rwanda; SDN = South Sudan; SOM = Somali Republic; TZA = Tanzania; UGA = Uganda; and ZMB = Zambia.

\begin{tabular}{|c|c|c|c|c|c|c|c|c|c|c|c|c|}
\hline & $B D I$ & $D R C^{*}$ & $E T H^{*}$ & $K E N$ & $M O Z^{*}$ & $M W I^{*}$ & $R W A$ & $S D N^{*}$ & $S O M^{*}$ & $T Z A$ & $U G A$ & $Z M B^{*}$ \\
\hline Carbon 2008 & 81 & 5285 & 818 & 2122 & 1276 & 363 & 87 & 768 & 352 & 3926 & 772 & 1599 \\
\hline 95\% CI_L & 61 & 4612 & 439 & 1012 & 1044 & 297 & 55 & 587 & 184 & 3053 & 613 & 1304 \\
\hline 95\% CI_U & 103 & 6075 & 1292 & 3167 & 1532 & 436 & 122 & 926 & 535 & 4694 & 947 & 1923 \\
\hline $\mathrm{RL}\left(\mathrm{Mt} \mathrm{yr}^{-1}\right)$ & -3.2 & -3.0 & -6.1 & -42.9 & -0.6 & 0.8 & -7.4 & -3.8 & -6.6 & 5.5 & -10.1 & -4.8 \\
\hline
\end{tabular}

is partly counterbalanced by carbon gains from increases in savannah and grassland area (Table 2). Carbon loss (as percentage of carbon stocks in 2002) was strongest in Rwanda (34\%), followed by Burundi, Kenya, and then Somalia, Uganda and Ethiopia (Table 4). In Rwanda, Burundi and Uganda, deforestation was the predominant driver of carbon stock changes between 2002 and 2008. In Tanzania and Malawi, biome shifts suggest net increases in above-ground live carbon stocks (Table 4), with deforestation emissions at least temporarily offset by increasing savannah and woodland area.

\section{Impacts of vegetation burning and rainfall on biome distribution}

Biomes differed strongly in their MAP (ANOVA with multi-comparison post-hoc Tukey HSD, $p<0.001$ ): forests $(1582 \pm 261 ;$ mean $\pm S D)$, woodlands $(1143 \pm 207)$, cropland $(1099 \pm 315)$, savannah $(1046 \pm 242)$, grassland $(627 \pm 206)$ and scrubland $(400 \pm 280)$. Fire probability was highest in woodlands and savannah (percentage burning between 2002 and 2008: $10.5 \pm 5.6$ and $10.3 \pm 5.2$, mean \pm SD) and significantly different from low fire probabilities in other biomes (ANOVA with multi-comparison post-hoc Tukey HSD, $p<0.001)$. Interannual variability in vegetation burning was high for each biome (Fig $2 c$ ) and possibly linked to annual rainfall patterns (Fig. 2a). IAP across the study region was significantly higher in 2004, 2006 and
2009 compared to other years (Fig. 2; ANOVA with multicomparison post-hoc Tukey HSD, $p<0.001$ ). Vegetation burning varied strongly among and within years and spatially. No significant correlations were found between annual rainfall and fire statistics (except for forests: $p<0.05, R^{2}{ }_{a d j}=0.55$; Ftest, $p<0.05$; Fig. $2 b$ ).

\section{Land management impacts on vegetation and fire patterns}

Vegetation composition and biome cover trends differed between land management types (Fig. 3; Appendix 1, Fig. S1, see supplementary material at Journals.cambridge.org/ENC)). Forest cover decreased in all management types except national parks (though leakage occurs and forest clearance immediately outside major national parks is a common problem; see Pfeifer et al. 2012a). The decrease in forest area compared with the 2002 baseline was strongest in unprotected areas, followed by game parks (which includes hunting areas, where people are allowed to reside within park boundaries), forest reserves and nature reserves (both should not have people living in them legally). Woodland area increased in nature reserves, national parks and game parks, but decreased in forest reserves and on unprotected land. Savannah cover increased considerably in all land management schemes, except national parks. Decrease in scrubland area was strongest on unprotected land. Biome burning was highest in forest reserves and on unprotected 
Figure 2 Interannual variability in precipitation and vegetation burning between 2002 and 2008 .

(a) Variation in interannual rainfall with significantly higher rainfall in 2004, 2006 and 2009 compared to other years (ANOVA with multi-comparison post-hoc Tukey HSD tests). (b) The percentage of forest pixels burning (dots) decreased significantly with increasing annual rainfall (linear regression model, $p<0.05, \mathrm{~F}$ test). (c) Biomes differed in burning probabilities; interannual variability of vegetation burning was high. (a)

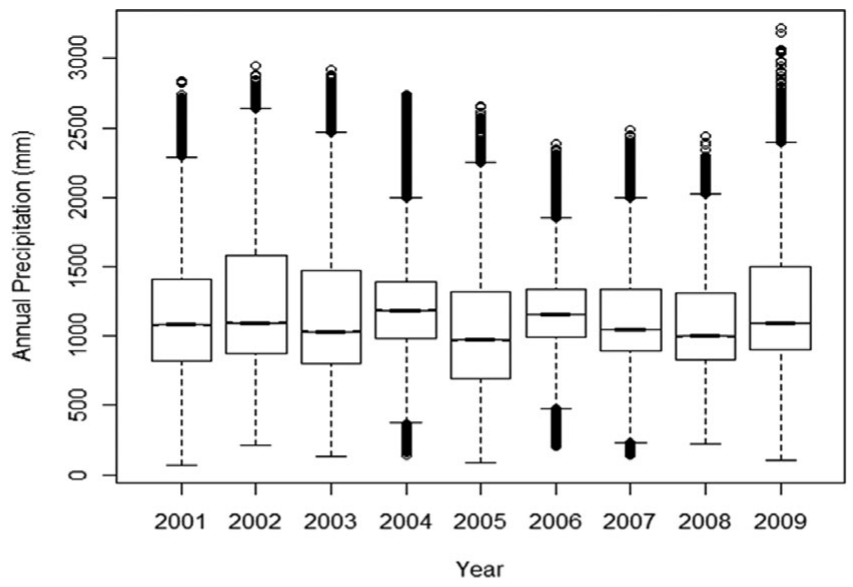

(b)

(c)

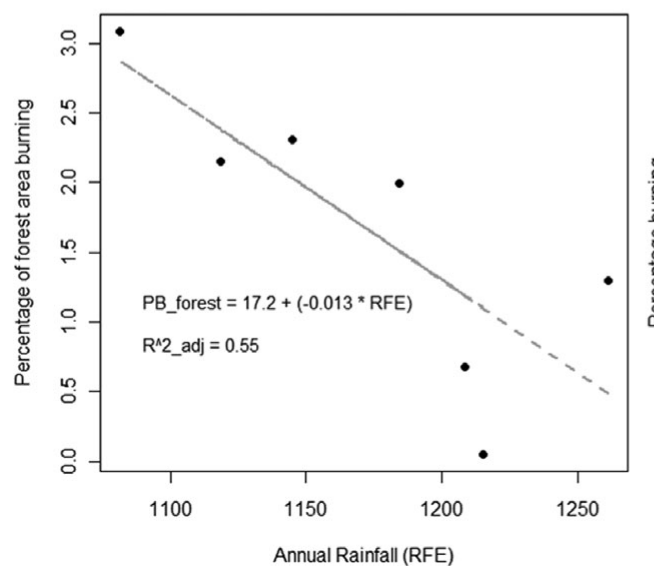

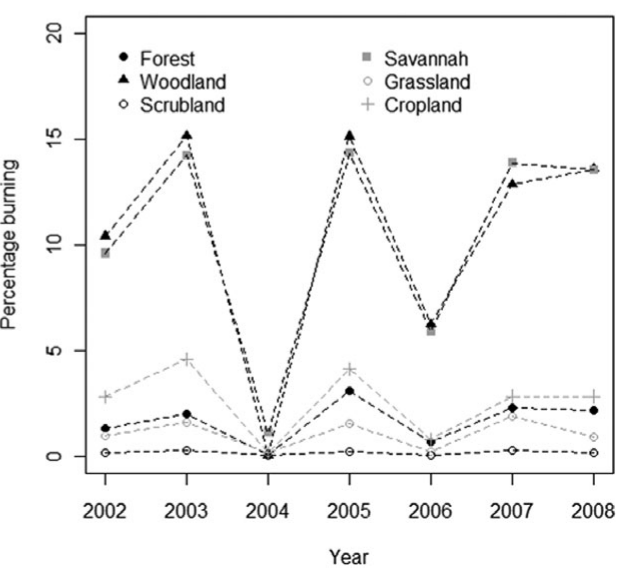

land (Fig. 4), but did not differ significantly between land management categories (ANOVA with multi-comparison post-hoc Tukey HSD, $p>0.5)$.

\section{DISCUSSION}

\section{Changes in forested areas and above-ground carbon}

African landscapes are the product of complex social, economic and ecological processes interacting over millennia. Forest conversion to cropland and forest degradation due to logging and fire is common in some areas, but is counterbalanced by increasing tree cover due to cropland abandonment and afforestation programmes in others (Wardell et al. 2003). Carbon stored in the aboveground living biomass of trees is a major carbon pool in tropical forest ecosystems that is most directly impacted by deforestation and forest degradation (Gibbs et al. 2007).

Deforestation rates at landscape scales can be derived using freely available land cover products derived from earth observation measurements (discussed in Pfeifer et al. 2012b). If the mean historic rate of deforestation is used as a predictor of future deforestation rates, this can provide practical a way forward for measuring emissions avoided as a result of REDD+ payments in a landscape-scale context, especially in regions where ground-based measurements are scarce (Griscom et al. 2009). In this paper, we have shown that carbon loss resulting from deforestation (5.1\% in the studied period) in East Africa translates to $288 \mathrm{Mt}(0.288 \mathrm{Pg} \mathrm{C})$ between 2002 and 2008, or $0.05 \mathrm{Pg} \mathrm{C} \mathrm{yr}^{-1}$. This is considerably lower than deforestation emissions reported for tropical Africa during the 1980s (DeFries et al. 2002: 0.10) and 1990s (DeFries et al. 2002: 0.14; Houghton 2003: 0.35; Achard et al. 2004: 0.16), either because there is increasingly less forest left to remove or because forest conservation efforts are starting to show. Carbon emissions from deforestation in 1980 (Houghton et al. 1987) were $0.0 \mathrm{Pg} \mathrm{C} \mathrm{yr}^{-1}$ for Burundi (compare with $0.0 \mathrm{Pg}$

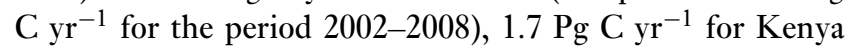
(0.04 Pg C yr ${ }^{-1}$ 2002-2008), 0.3 Pg C yr ${ }^{-1}$ for Rwanda (0.01 $\mathrm{Pg} \mathrm{C} \mathrm{yr}{ }^{-1}$ 2002-2008), 4.9 $\mathrm{Pg} \mathrm{C} \mathrm{yr}^{-1}$ for Tanzania (0.01 Pg $\mathrm{C} \mathrm{yr}^{-1}$ 2002-2008) and 2.2 $\mathrm{Pg} \mathrm{C} \mathrm{yr}^{-1}$ for Uganda (0.01 Pg C $\mathrm{yr}^{-1}$ 2002-2008). Pan et al. (2011) suggested that the global deforestation emission is mostly compensated by $\mathrm{C}$ uptakes in tropical regrowth and intact forests.

With the exception of Tanzania and northern Malawi, East Africa's countries are sources of carbon emissions. Emissions

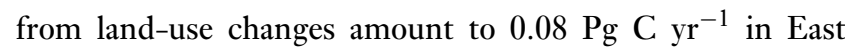
Africa and are generally comparable to net annual carbon fluxes reported for tropical Africa in the 1980s (DeFries et al. 2002: 0.09 $\mathrm{Pg} \mathrm{C} \mathrm{yr}^{-1}$; Houghton 2003: 0.28 $\mathrm{Pg} \mathrm{C} \mathrm{yr}^{-1}$ ) and in 

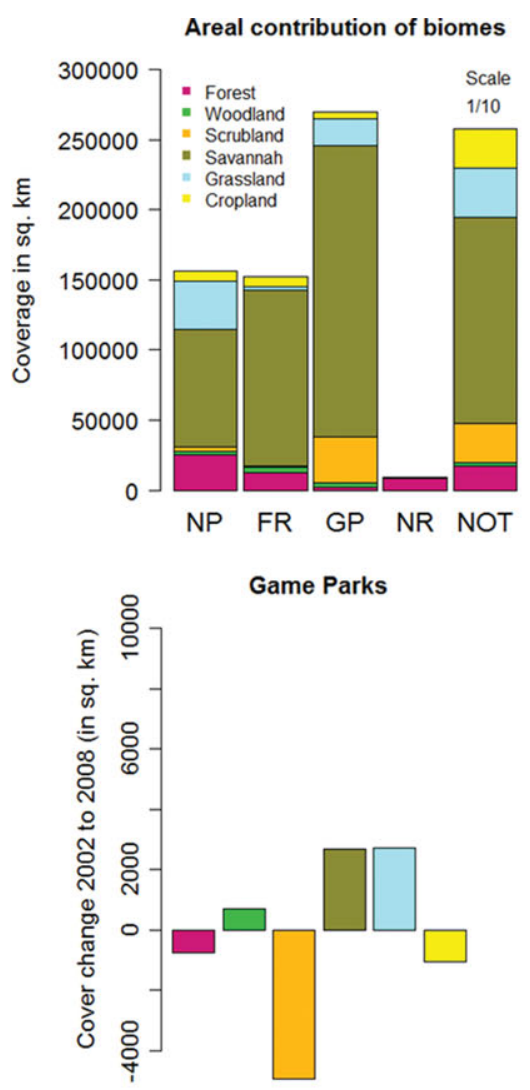
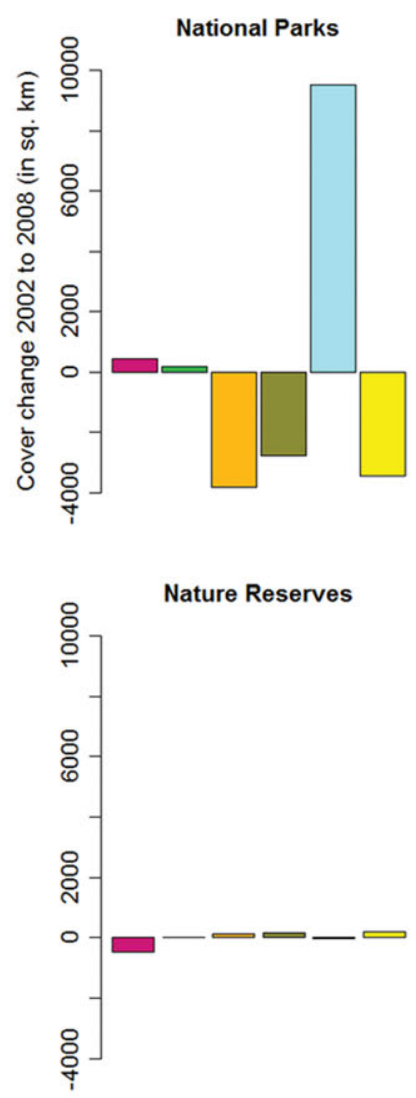
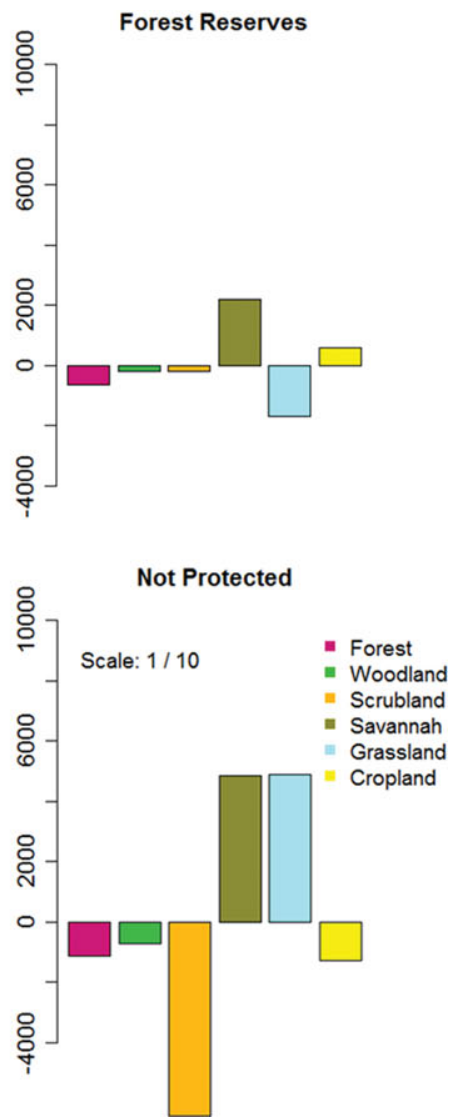

Figure 3 Vegetation composition and cover trends under different land management between 2002 and 2008. Nature reserves (NR) contain predominantly forests; woody biomes dominate in game parks (GP), forest reserves (FR) and unprotected areas (NOT). Protected forest area is highest in national parks (NP). Note the scale (Area/10) for unprotected areas.

the 1990s (DeFries et al. 2002: 0.12 $\mathrm{Pg} \mathrm{Cyr}^{-1}$; Houghton 2003: $0.35 \mathrm{Pg} \mathrm{C} \mathrm{yr}^{-1}$ ). Carbon loss from deforestation (predominant in Uganda, Rwanda and Burundi) and forest degradation to woodlands, scrubland or savannah $(30 \mathrm{Mt}, 9 \mathrm{Mt}$ and 259 Mt respectively, between 2002 and 2008) is counterbalanced by transition of woodlands and savannah to forest (13 Mt and $168 \mathrm{Mt}$ between 2002 and 2008). This underlines how accounting for above-ground carbon stocks in woody biomes can change a country's RL considerably (Table 4), especially in Africa, where carbon storage appears evenly distributed between forests $(54.1 \%)$ and other woody vegetation (45.9\%) (Baccini et al. 2012).

Overall, the magnitude of carbon estimates for forests in East African countries derived in our study are broadly similar to findings from other sources (Table 5). Our study underestimates forest-based carbon in Kenya and Tanzania compared to assessments by the Food and Agriculture Organization of the United Nations (FAO 2010), probably because the FAO definition of forests is more inclusive of some savannah formations (Table 5). However, we find more pronounced carbon losses caused by deforestation (for example in Burundi); the 50\% carbon loss identified in Rwanda contradicts the carbon increase reported by the FAO for the 2000-2010 period (Table 5). Countrylevel estimates of carbon stocks reported by the FAO are based on forest inventory data and are known to be biased, owing to inconsistent methods and inadequate sampling for extrapolation at national scales (Gibbs et al. 2007).

Although our study presents independent estimates of carbon fluxes in East Africa, interpretations for management should be handled cautiously, and we emphasize that groundbased measurements should be preferred where sufficient coverage exists. In particular, we draw attention to three potential sources of error in the carbon flux estimates presented here. Firstly, using biome-average carbon estimates can introduce bias in estimates of deforestation emissions, especially if the number of plots sampled is low and if the forests that are cleared differ systematically from those measured for carbon; see Gibbs et al. 2007). Carbon storage within biomes varies spatially (see confidence intervals in Table 1), because of vegetation growth conditions along bioclimatic gradients and species composition (Gibbs et al. 2007; Shirima et al. 2011), thus introducing large uncertainties into estimates of terrestrial carbon emissions (Baccini et al. 2012).

Secondly, we note that the spatial resolution of MODIS land cover (500-m pixels) hampers accounting for carbon loss resulting from degradation or fragmentation at the sub-pixel scale. Probable confusion between grasslands and croplands due to spectral similarity will overestimate carbon gains 
Forest burning

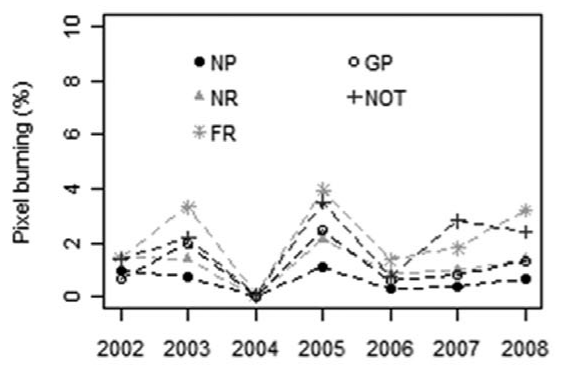

Scrubland burning

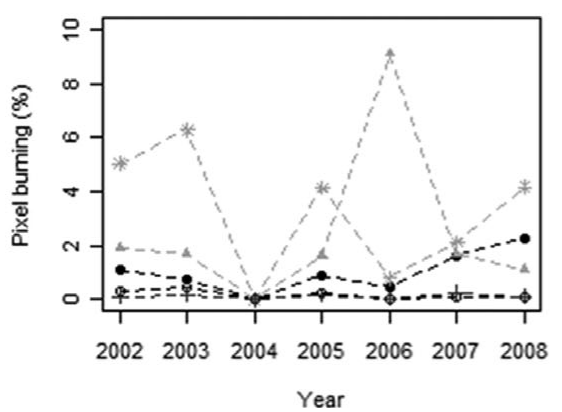

Woodland burning

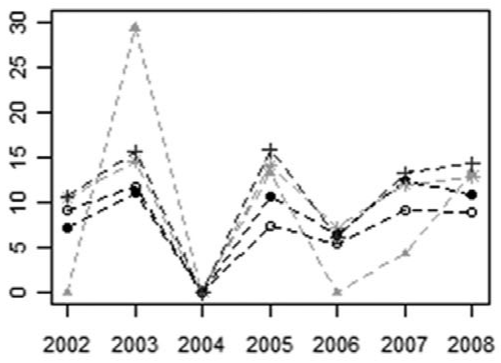

Grassland burning

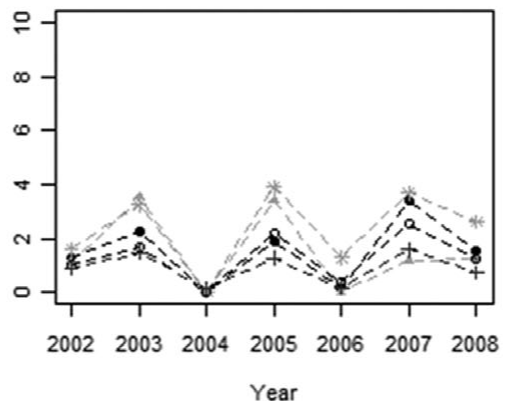

Savannah burning

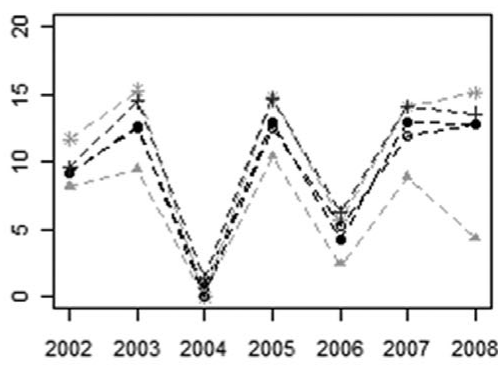

Cropland burning

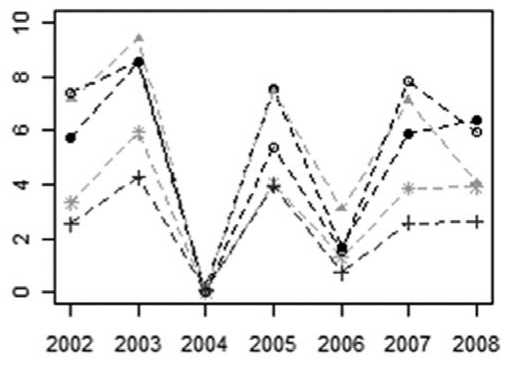

Year

Figure 4 Vegetation burning between 2002 and 2008 within different land management schemes. Burning dominates woody biomes and croplands, but is less likely in forests and grasslands. Forest, woodland and savannah burning were least likely in national parks and game parks.

Table 5 Comparison of studies on forest-stored carbon in five East African countries. Carbon estimates in Mt C ha ${ }^{-1}$. Most of the carbon in Tanzania was stored in savannah-type vegetation (3009 $\mathrm{Mt} \mathrm{C} \mathrm{ha}^{-1}$ in 2002, $3072 \mathrm{Mt} \mathrm{Cha}^{-1}$ in 2008) that may have been classified as forest in some regions by FAO. In Kenya, $377 \mathrm{Mt} \mathrm{C} \mathrm{ha}^{-1}$ (2002) and $358 \mathrm{Mt} \mathrm{C} \mathrm{ha}^{-1}$ (2008) were stored in savannah-type vegetation. ${ }^{1}$ Estimates based on compilations of forest inventory data for forest-averaged carbon (Brown 1997; Achard et al. 2004) applied to the Global Land Cover 2002 global land cover map for the year 2000. ${ }^{2}$ Estimates based on forest-averaged carbon accounting for anthropogenic forest disturbance (Gibbs \& Brown 2007). ${ }^{3}$ Carbon stocks in living forest biomass (FAO 2010): forests are defined by $10 \%$ canopy cover density for developing countries, minimum tree height $=7 \mathrm{~m}$, minimum area $=10 \mathrm{ha}$.

\begin{tabular}{|c|c|c|c|c|c|c|c|c|c|c|}
\hline \multirow[b]{2}{*}{ Country } & \multicolumn{2}{|c|}{$\begin{array}{c}\text { This study: evergreen } \\
\text { forests only }\end{array}$} & \multicolumn{2}{|c|}{$\begin{array}{l}\text { This study: evergreen } \\
\text { forests and moodland }\end{array}$} & \multicolumn{2}{|c|}{$\begin{array}{c}\text { From Gibbs et al. } \\
2007 \\
\end{array}$} & \multicolumn{4}{|c|}{$\overline{F A A O^{3}}$} \\
\hline & 2002 & 2008 & 2002 & 2008 & $2000^{1}$ & $2000^{2}$ & 1990 & 2000 & 2005 & 2010 \\
\hline$\overline{\text { Burundi }}$ & $\begin{array}{l}44 \\
{[31-59]}\end{array}$ & $\begin{array}{l}15 \\
{[8-22]}\end{array}$ & $\begin{array}{l}45 \\
{[32-61]}\end{array}$ & $\begin{array}{l}16 \\
{[9-23]}\end{array}$ & 55 & 9 & 25 & 19 & 18 & 17 \\
\hline Kenya & $\begin{array}{l}240 \\
{[113-371]}\end{array}$ & $\begin{array}{l}216 \\
{[105-332]}\end{array}$ & $\begin{array}{l}250 \\
{[119-383]}\end{array}$ & 226 & 339 & 163 & 525 & 503 & 489 & 476 \\
\hline Rwanda & $\begin{array}{l}113 \\
{[69-161]}\end{array}$ & $\begin{array}{l}57 \\
{[33-83]}\end{array}$ & $\begin{array}{l}114 \\
{[69-163]}\end{array}$ & $\begin{array}{l}58 \\
{[33-84]}\end{array}$ & 48 & 6 & 35 & 18 & 35 & 39 \\
\hline Tanzania & $\begin{array}{l}542 \\
{[463-636]}\end{array}$ & $\begin{array}{l}485 \\
{[408-577]}\end{array}$ & $\begin{array}{l}623 \\
{[518-736]}\end{array}$ & $\begin{array}{l}616 \\
{[497-737]}\end{array}$ & 2409 & 1281 & 2505 & 2262 & 2139 & 2019 \\
\hline Uganda & $\begin{array}{l}401 \\
{[334-487]}\end{array}$ & $\begin{array}{l}328 \\
{[272-399]}\end{array}$ & $\begin{array}{l}409 \\
{[339-497]}\end{array}$ & $\begin{array}{l}331 \\
{[274-403]}\end{array}$ & 479 & 429 & 171 & 140 & 124 & 109 \\
\hline
\end{tabular}

through increases in grassland cover, although the impact of these uncertainties on large-scale carbon assessments is less important owing to the low aboveground carbon storage in these systems. Woodland and savannah biomes are difficult to distinguish based on their spectral signatures, although more clearly separated from forests, most crops and scrubland. Thus, uncertainties in the estimation of carbon flows resulting from transitions between woody biomes remain high. Comparisons of MODIS biomes with field surveys carried out in Tanzania indicate that small-scale farming within scrubland and savannah biomes is difficult to distinguish from scrublands using remote sensing $(32 \%$ of cropland plots were within MODIS scrubland pixels), but this equally applies to higher-resolution images $(20 \times 20$ to 
$30 \times 30 \mathrm{~m}^{2}$ ) provided by Landsat and SPOT (M. Pfeifer, unpublished data 2011).

Thirdly, we limited our monitoring to one of the five carbon pools required by the Intergovernmental Panel for Climate Change (IPCC) reporting (IPCC 2007). Carbon release from soil especially during forest to cropland conversion is high (Houghton 2003); soil carbon change will ultimately alter our findings.

\section{Fire impacts on biome shifts}

Fire frequencies differ among biomes (dominating in woodlands and savannah) and seasons, reflecting differences in rainfall and build-up of flammable stock as sources of ignition (Smit et al. 2010). Savannah fires are usually followed by tree regrowth, but contribute significantly to short-term carbon emissions in East Africa. Field data on fire impacts on forest biomass are rare for East Africa. Our analyses indicate that forest fires, although infrequent, reduce biomass and increase the probability of forest degradation.

Fire is assumed to suppress woody cover in mesic and wet savannahs (Higgins et al. 2007). However, resprouting of savannah trees after fire is common and low-intensity fires are needed to maintain biomass (Ryan \& Williams 2011). Non-detection of fire impacts on woodland and savannah cover implies that fire impacts and/or human pressures (since fires are often human-ignited) are below sustainability thresholds, savannahs being a model system of historical human-ecosystem interactions (Marchant 2010). Local-scale studies show fire- and land-use associated degradation, with negative effects on carbon storage and biomass in Kenyan and Tanzanian Acacia-dominated woody savannah biomes (Okello et al. 2007; Cochard \& Edwards 2011). Such finescale impacts are difficult to detect at the scales at which this study was conducted, but could potentially be captured by refining land cover types, using more detailed remote sensing maps and enlisting community engagement for participatory forest assessment (Topp-Jørgensen et al. 2005).

\section{Rainfall and biome burning}

We detected significant correlations between annual rainfall and forest burning, despite the complexity of the East African climate driven by the biannual north-south migration of the inter-tropical convergence zone, the Indian Ocean Dipole (Marchant et al. 2006) and El Niño Southern Oscillation (ENSO) climate variability (Schreck \& Semazzi 2004). East Africa's rainfall between 2002 and 2008 carried ENSO signals (El Niño events in the Pacific in 2002, 2004 and 2006, and the La Niña event in 2007), which were correlated with fire frequency (NOAA [National Oceanic and Atmospheric Administration] 2011). Greater burning was seen the next burning season after the onset of the ENSO. This supports findings that ENSO events are linked to burned area in tropical East Africa (Riaño et al. 2007) although further investigation is needed to assess the potential linkages with sea surface temperature variability in the Indian Ocean.

\section{Vegetation changes in relation to land management}

Land management in East Africa is associated with different land use restrictions. Typically, national parks and game parks are well patrolled and exclude settlement. Forest reserves are managed for 'sustainable' timber extraction and catchment protection and are less well funded, while nature reserves are designed to protect forest biodiversity (Caro et al. 2009).

Between 2002 and 2008, game parks experienced higher rates of forest loss compared to other protected areas, probably a result of synergistic effects of fire and herbivore activity in woody cover suppression (Holdo et al. 2009). Deforestation encroachment across boundaries of nature and forest reserves is common. However, the decline in East African forests dominates on unprotected land $\left(>11000 \mathrm{~km}^{2}\right)$. Fire frequencies differ slightly between land management types, with more frequent fires in less well patrolled protected areas, suggesting that humans contribute to fire ignitions. However, these differences in fire may also reflect different vegetation composition, with a higher percentage of fire-prone vegetation in unprotected areas, game reserves and forest reserves (see Fig. 3).

Spatial variability in protected area effectiveness is high within land management categories. Some reserves may have increased their forest area, even if on the macroscale these increases are overtaken by forest loss in other reserves. The size of the forest within a protected area appears to have measurable effects on its susceptibility to changes, with smaller forests being more likely to experience a decrease (Pfeifer et al. 2012a). Detailed analyses across spatial scales, and accounting for differences in park rule implementation between countries, are necessary before drawing final management conclusions.

\section{Implications for forest management and carbon assessment}

Our approach provides a landscape scale context for assessing and monitoring a country's or region's land-use change and associated carbon changes. Limitations of our approach (due to classification errors and spatial resolution) do not allow for replacing local and high-spatial resolution monitoring activities (such as REDD+ projects carried out in Tanzania), which can detect forest degradation and fragmentation (Burgess et al. 2010; Skutsch \& Ba 2011). However, our approach can potentially make these higheffort activities more cost- and time-effective, by focusing them toward hotspots of carbon flux. Combining biomechange maps with fire products, climate data, land surface trait information and biodiversity maps can help to inform subsequent adaptive management plans, by aiding in the detection of drivers that underlie carbon emissions at the landscape scale and identifying biodiversity cobenefits of 
adaptive land management (Busch et al. 2010; Hannah 2010; Strassburg et al. 2012).

Possible management in East Africa may include controlled burning of areas around forests prior to fire seasons, which could increase carbon storage by increasing tree densities and create local 'carbon sinks' (Scheiter \& Higgins 2009). Early season burning in woody biomes of communal areas can break up fuel loads for later fires, preventing high intensity fire damage (Laris \& Wardell 2006). However, accompanying studies are necessary to evaluate fire suppression effects on fire-adapted vegetation assemblages in East Africa, to avoid compromising other conservation targets, such as biodiversity (Masocha et al. 2011).

Protected area information, as provided for example by the World Database on Protected Areas, can aid in identifying country-specific land management solutions. As our analyses show, adjusting the protection status of forested areas towards national parks may offer viable long-term solutions for forest and carbon conservation. However, alternative sources for energy and income will have to be provided to avoid increasing poverty and leakage, in other words the displacement of biomass consumption to the nearest unprotected forest (Thomson et al. 2010; Fisher et al. 2011; Pfeifer et al. 2012a).

\section{CONCLUSIONS}

Land-use change detection can be based on global earth observation products providing a rapid assessment tool for estimating landscape scale changes in carbon and forest cover. Four main conclusions are drawn from our East African analyses. Firstly, forest and carbon losses are on-going, albeit at probably lower rates compared to the last century. Secondly, carbon gains occur in some areas, seen in the increasing extent of woody biomes such as Acacia-Commiphora savannah or Miombo woodland. Thirdly, fire management schemes (if effective) may be able to reduce carbon emissions from woodlands and woody savannah. Fourth, national parks function as effective carbon stores and sinks and so could make a contribution towards national delivery of REDD + , however, REDD will ultimately fail unless the drivers of deforestation and degradation are addressed.

\section{ACKNOWLEDGEMENTS}

Marion Pfeifer was supported by the Marie Curie IntraEuropean fellowship IEF Programme (EU FP7-People-IEF2008 Grant Agreement ${ }^{\circ}$ 234394). Ruth Swetnam, Philip Platts, Simon Willcock and Simon Lewis were funded by the Leverhulme Trust through the Valuing the Arc Programme. Simon Lewis is funded by a Royal Society University research fellowship. Rob Marchant and Philip Platts were additionally supported by the Ministry for Foreign Affairs of Finland through the CHIESA Project. We are grateful to Minnie Wong (University of Maryland) for provision of MODIS fire hotspots data. We acknowledge the British Institute in
East Africa for logistic support during field work. We thank anonymous reviewers for their helpful comments.

\section{References}

Achard, F., Eva, H.D., Mayaux, P., Stibig, H.-J. \& Belward, A. (2004) Improved estimates of net carbon emissions from land cover change in the tropics for the 1990s. Global Biogeochemical Cycles 18: GB2008. doi:10.1029/2003GB002142.

Ahrends, A., Burgess, N.D., Milledge, S.A.H., Bulling, M.T., Fisher, B., Smart, J.C., Clarke, G.P., Mhoro, B.E. \& Lewis, S.L. (2010) Predictable waves of sequential forest degradation and biodiversity loss spreading from an African city. Proceedings of the National Academy of Sciences USA 107: 1455614561.

Archibald, S., Nickless, A., Govender, N., Scholes, R.J. \& Lehsten, V. (2010) Climate and the inter-annual variability of fire in southern Africa: a meta-analysis using long-term field data and satellite-derived burnt area data. Global Ecology and Biogeography 19: 794-804.

Baccini, A., Goetz, S.J., Walker, W.S., Laporte, N.T., Sun, M., Sulla-Menashe, D., Hackler, J., Beck, P.S.A., Dubayah, R., Friedl, M.A., Samanta, S. \& Houghton, R.A. (2012) Estimated carbon dioxide emissions from tropical deforestation improved by carbon-density maps. Nature Climate Change 2: 182-185.

Bond, W.J., Woodward, F.I. \& Midgley, G.F. (2005) The global distribution of ecosystems in a world without fire. Nem Phytologist 165: 525-537.

Brncic, T.M., Willis, K.J., Harris, D.J. \& Washington, R. (2007) Culture or climate? The relative influences of past processes on the composition of the lowland Congo rainforest. Philosophical Transactions of the Royal Society London B 362: 229-242.

Brown, S. (1997) Estimating biomass and biomass change of tropical forests: a primer. FAO Forestry Paper no. 134. FAO, Rome, Italy.

Bucini, G. \& Hanan, N.P. (2007) A continental-scale analysis of tree cover in African savannas. Global Ecology and Biogeography 16: 593-605.

Burgess, N.D., D'Amico Hales, J., Underwood, E. \& Dinerstein, E. (2004) Terrestrial Ecoregions of Africa and Madagascar: A Continental Assessment. Washington, DC, USA: Island Press.

Burgess, N.D., Bahane, B., Clairs, T., Danielsen, F., Dalsgaard, S., Funder, M., Hagelberg, N., Harrison, P., Haule, C., Kabalimu, K., Kilahama, F., Kilawe, E., Lewis, S.L., Lovett, J.C., Lyatuu, G., Marshall, A.R., Meshack, C., Miles, L., Milledge, S.A.H., Munishi, P.K.T., Nashanda, E., Shirima, D., Swetnam, R.D., Willcock, S., Williams, A. \& Zahabu, E. (2010) Getting ready for REDD +in Tanzania: a case study of progress and challenges. Oryx 44: 339-351.

Busch, J., Godoy, F., Turner, W.R. \& Harvey, C.A. (2010) Biodiversity co-benefits of reducing emissions from deforestation under alternative reference levels and levels of finance. Conservation Letters 4: 101-115.

Caro, T., Gardner, T.A., Stoner, C., Fitzherbert, E. \& Davenport, T.R.B. (2009) Assessing the effectiveness of protected areas: paradoxes call for pluralism in evaluating conservation performance. Diversity and Distributions 15: 178-182.

Cochard, R. \& Edwards, P.J. (2011) Tree dieback and regeneration in secondary Acacia zanzibarica woodlands on an abandoned cattle ranch in coastal Tanzania. Fournal of Vegetation Science 22: 490502 . 
Cohen, W.B., Maiersperger, T.K., Turner, D.P., Ritts, W.D., Pflugmacher, D., Kennedy, R.E., Kirschbaum, A., Running, S.W., Costa, M. \& Gower, S.T. (2006) MODIS land cover and LAI collection 4 product quality across nine sites in the western hemisphere. IEEE Transactions on Geoscience and Remote Sensing 44: 1843-1857.

DeFries, R.S., Houghton, R.A., Hansen, M.C., Field, C.B., Skole, D. \& Townshend, J. (2002) Carbon emissions from tropical deforestation and regrowth based on satellite observations for the 1980s and 1990s. Proceedings of the National Academy of Sciences USA 99: 14256-14261.

Disney, M.I., Kalogirou, V., Lewis, P., Prieto-Blanco, A., Hancock, S. \& Pfeifer, M. (2010) Simulating the impact of discrete-return LiDAR system and survey characteristics over young conifer and broadleaf forests. Remote Sensing of Environment 114: 1546-1560.

Ebeling, J. \& Yasue, M. (2008) Generating carbon finance through avoided deforestation and its potential to create climatic, conservation and human development benefits. Philosophical Transactions of the Royal Society London B 363: 1917-1923.

Englhart, S., Keuck, V. \& Siegert, F. (2011) Aboveground biomass retrieval in tropical forests. The potential of combined X- and L-band SAR data use. Remote Sensing of Environment 115: 1260 1271.

FAO (2010) Global Forest Resources Assessment 2010. Main report [www document]. URL http://www.fao.org/docrep/013/ i1757e/i1757e.pdf

Fisher, B., Lewis, S.L., Burgess, N.D., Malimbwi, R.E., Munishi, P.K., Swetnam, R.D., Turner, R.K., Willcock, S. \& Balmford, A. (2011) Implementation and opportunity costs of reducing deforestation and forest degradation in Tanzania. Nature Climate Change 1: 161-164.

Friedl, M.A., Sulla-Menashe, D., Tan, B., Schneider, A., Ramankutty, N., Sibley, A. \& Huang, X. (2010) MODIS Collection 5 global land cover: algorithm refinements and characterization of new datasets. Remote Sensing of Environment 114: 168-182.

Gibbs, H.K. \& Brown, S. (2007) Geographical distribution of woody biomass carbon stocks in tropical Africa: an updated database for 2000 [www document]. URL http://cdiac.ornl.gov/ epubs/ndp/ndp055/ndp055b.html

Gibbs, H.K., Brown, S., O Niles, J. \& Foley, J.A. (2007) Monitoring and estimating tropical forest carbon stocks: making REDD a reality. Environmental Research Letters 2: 045023 [www document]. URL http://iopscience.iop.org/1748-9326/2/4/045023

Giglio, L., Descloitres, J., Justice, C.O. \& Kaufman, Y.J. (2003) An enhanced contextual fire detection algorithm for MODIS. Remote Sensing of Environment 87: 273-382.

Godoy, F.L., Tabor, K., Burgess, N.D., Mbilinyi, B.P., Kashaigili, J. \& Steininger, M. (2011) Deforestation and $\mathrm{CO}_{2}$ emissions in coastal Tanzania from 1990 to 2007. Environmental Conservation 39: $62-71$.

Griscom, B., Shoch, D., Stanley, B., Cortez, R. \& Virgilio, N. (2009) Sensitivity of amounts and distribution of tropical forest carbon credits depending on baseline rules. Environmental Science and Policy 12: 897-911.

Hall, J., Burgess, N., Lovett, J., Mbilinyi, B. \& Gereau, R.E. (2009) Conservation implications of deforestation across an elevational gradient in the Eastern Arc Mountains, Tanzania. Biological Conservation 142: 2510-2521.

Hannah, L. (2010) A global conservation system for climate-change adaptation. Conservation Biology 24: 70-77.
Harper, G.J., Steininger, M.K., Tucker, C.J., Juhn, D. \& Hawkins, F. (2007) Fifty years of deforestation and forest fragmentation in Madagascar. Environmental Conservation 34: 325-333.

Higgins, S.I., Bond, W.J., February, E.C., Bronn, A., Euston-Brown, D.I., Enslin, B., Govender, N., Rademan, L., O'Regan, S., Potgieter, A.L., Scheiter, S., Sowry, R., Trollope, L. \& Trollope, W.S. (2007) Effects of four decades of fire manipulation on woody vegetation structure in savanna. Ecology 88: 1119 1125 .

Hijmans, R.J., Cameron, S.E., Parra, J.L., Jones, P.G. \& Jarvis, A. (2005) Very high resolution interpolated climate surfaces for global land areas. International fournal of Climatology 25: 19651978.

Hodgens, J. (2002) Validation of the consistent year-v003 MODIS land cover product. MODIS User Guide [www document]. URL http://www-modis.bu.edu/landcover/userguidelc/consistent. htm

Holdo, R.M., Holt, R.D. \& Fryxell, J.M. (2009) Grazers, browsers and fire influence the extent and spatial pattern of tree cover in the Serengeti. Ecological Applications 19: 95-109.

Houghton, R.A. (2003) Revised estimates of the annual net flux of carbon to the atmosphere from changes in land use and land management 1850-2000. Tellus 55B: 378-390.

Houghton, R.A., Boone, R.D., Fruci, J.R., Hobbie, J.E., Mellilo, J.M., Palm, C.A., Peterson, B.J., Shaver, G.R. \& Woodwell, G.M. (1987) The flux of carbon from terrestrial ecosystems to the atmosphere in 1980 due to changes in land use: geographic distribution of the global flux. Tellus 39B: 122-139.

IPCC (2007) Fourth Assessment Report (AR4). Climate change 2007: Synthesis Report. IPCC, Geneva, Switzerland [www document]. URL http://www.ipcc.ch/publications_and_data/ ar4/syr/en/main.html

IUCN \& UNEP (2010) The World Database on Protected Areas Cambridge, UK. Version 2010 [www document]. URL http://www.wdpa.org/AnnualRelease.aspx

Keeley, J.E., Fotheringham, C.J. \& Morais, M. (1999) Re-examining fire suppression impacts on brushland fire regimes. Science 284 : $1829-1833$.

Kgope, B.S., Bond, W.J. \& Midgley, G.F. (2010) Growth responses of African savanna trees implicate atmospheric $\left[\mathrm{CO}_{2}\right]$ as a driver of past and current changes in savanna tree cover. Austral Ecology 35: 451-463.

Laris, P. \& Wardell, D.A. (2006) Good, bad or 'necessary' evil? Re-interpreting the colonial burning experiments in the savanna landscapes of West Africa. Geographic Fournal 172: 271-90.

Laurance, W.F.A. (2007) New initiative to use carbon trading for tropical forest conservation. Biotropica 39: 20-24.

Lewis, S.L., Lopez-Gonzalez, G., Sonke, B., Affum-Bafoe, K., Baker, T.R., Ojo, L.O., Pillips, O.L., Reitsma, J.M., White, L., Comiskey, J.A., Djuikouo, K.M.N., Ewango, C.E., Feldpausch, T.R., Hamilton, A.C., Gloor, M., Hart, T., Hladik, A., Lloyd, J., Lovett, J.C., Makana, J.R., Malhi, Y., Mbago, F.M., Ndangalasi, H.J., Peacock, J., Peh, K.S., Sheil, D., Sunderland, T., Swaine, M.D., Taplin, J., Taylor, D., Thomas, S.C., Votere, R. \& Wöll, H. (2009) Increasing carbon storage in intact African tropical forests. Nature 457: 1003-1007.

Lucas, R.M., Mitchell, A.L., Rosenqvist, A., Proisy, C., Melius, A. \& Ticehurst, C. (2007) The potential of L-band SAR for quantifying mangrove characteristics and change: a case study for the tropics. Aquatic Conservation. Marine and Freshmater Ecosystems 17: 254264. 
Marchant, R. (2010) Understanding complexity in savannas: climate, biodiversity and people. Current Opinion in Environmental Sustainability 2: 101-108.

Marchant, R., Mumbi, C., Behera, S. \& Yamagata, T. (2006) The Indian Ocean dipole. The unsung driver of climatic variability in East Africa. African Fournal of Ecology 45: 4-16.

Masocha, M., Skidmore, A.K., Poshiwa, X. \& Prins, H.H.T. (2011) Frequent burning promotes invasions of alien plants into a mesic African savannah. Biological Invasions 13: 1641-1648.

Návar-Chaidez, J. (2010) Biomass allometry for tree species of northwestern Mexico. Tropical and Subtropical Agroecosystems 12: 507-519.

Návar-Chaidez, J. (2011) The spatial distribution of aboveground biomass in tropical forests of Mexico. Tropical and Subtropical Agroecosystems 14: 149-158.

Nicholson, S.E. (2000) The nature of rainfall variability over Africa on time scales of decades to millennia. Global and Planetary Change 26: $137-158$.

NOAA (2011) National Oceanic and Atmospheric Administration's Oceanic Niño Index [www document]. URL http://ggweather.com/enso/oni.htm

Okello, B.D., Young, T.P., Riginos, C., Kelly, D. \& O'Connor, T.G. (2007) Short-term survival and long-term mortality of Acacia drepanolobium after a controlled burn. African Fournal of Ecology 46: 395-401.

Pan, Y., Birdsey, R.A., Fang, J., Houghton, R., Kauppi, P.E., Kurz, W.A., Phillips, O.L., Shvidenko, A., Lewis, S.L., Canadell, J.G., Ciais, P., Jackson, R.B., Pacala, S.W., McGuire, A.D., Piao, S., Rautiainen, A., Sitch, S. \& Hayes, D. (2012) A Large and Persistent Carbon Sink in the World's Forests. Science 333: 988993.

Pfeifer, M., Burgess, N.D., Swetnam, R.D., Platts, P.J., Willcock, S. \& Marchant, R. (2012a) Protected areas: mixed success in conserving East Africa's evergreen forests. PLoS ONE 7: e39337. doi:10.1371/journal.pone.0039337.

Pfeifer, M., Disney, M., Quaife, T. \& Marchant, R. (2012b) Terrestrial ecosystems from space: a review of earth observation products for macroecology applications. Global Ecology and Biogeography 21: 603-624.

Riaño, D., Ruiz, J.A.M., Martinez, J.B. \& Ustin, S.L. (2007) Burned area forecasting using past burned area records and Southern Oscillation Index for tropical Africa (1981-1999). Remote Sensing of Environment 107: 571-581.

Ryan, C.M. \& Williams, M. (2011) How does fire intensity and frequency affect miombo woodland tree populations and biomass. Ecological Applications 21: 48-60.

Scheiter, S. \& Higgins, S.I. (2009) Impacts of climate change on the vegetation of Africa: an adaptive dynamic vegetation modelling approach. Global Change Biology 15: 2224-2246.

Schreck III, C.J. \& Semazzi, F.H.M. (2004) Variability of the recent climate of Eastern Africa. International Fournal of Climatology 24 : 681-701.
Shirima, D.D., Munishi, P.K.T., Lewis, S.L., Burgess, N.D., Marshall, A.R., Balmford, A., Swetnam, R.D. \& Zahabu, E.M. (2011) Carbon storage, structure and composition of Miombo woodlands in Tanzania's Eastern Arc Mountains. African Fournal of Ecology 49: 332-342.

Skutsch, M.M. \& Ba, L. (2011) Crediting carbon in dry forests: the potential of community forest management in West Africa. Forest Policy and Economics 12: 264-270.

Smit, I.P.J., Asner, G.P., Govender, N., Kenny-Bowdoin, T., Knapp, D.E. \& Jacobson, J. (2010) Effects of fire on woody vegetation structure in African savannah. Ecological Applications 20: $1865-1875$.

Strassburg, B.B.N., Rodrigues, A.S.L., Gusti, M., Balmford, A., Fritz, S., Obersteiner, M., Turner, K.R. \& Brooks, T.M. (2012) Impacts of incentives to reduce emissions from deforestation on global species extinctions. Nature Climate Change 2: 350 355.

Thomson, A.M., Calvin, K.V., Chini, L.P., Hurtt, G., Edmonds, J.A., Bond-Lamberty, B., Frolking, S., Wise, M.A. \& Janetos, A.C. (2010) Climate mitigation and the future of tropical landscapes. Proceedings of the National Academy of Sciences USA 107: 19633-19638.

Topp-Jørgensen, E., Poulsen, M.K., Lund, J.F. \& Massao, J.F. (2005) Community-based monitoring of natural resource use and forest quality in montane forests and Miombo woodlands of Tanzania. Biodiversity and Conservation 14: 2653 2677.

Wardell, D.A., Reenberg, A. \& Tøttrup, C. (2003) Historical footprints in contemporary land use systems: forest cover changes in savannah woodlands in the Sudano-Sahelian zone. Global Environmental Change 13: 235-254.

Willcock, S., Phillips, O.L., Platts, P.J., Balmford, A., Burgess, N.D., Lovett, J.C., Ahrends, A., Bayliss, J., Doggart, N., Doody, K., Fanning, E., Green, J., Hall, J., Howell, K.L., Marchant, R., Marshall, A.R., Mbilinyi, B., Munishi, P.K.T., Owen, N., Swetnam, R.D., Topp-Jorgensen, E.J. \& Lewis, S.L. (2012) Towards regional, error-bounded landscape carbon storage estimates for data-deficient areas of the world. PLoS One 7: e44795.

Williams, C.A., Hanan, N.P., Neff, J.C., Scholes, R.J., Berry, J.A., Denning, A.S. \& Baker, D.F. (2007) Africa and the global carbon cycle. Carbon Balance and Management 2: 3. doi:10.1186/1750 0680-2-3.

Wulder, M.A., White, J.C., Fournier, R.A., Luther, J.E. \& Magnussen, S. (2008) Spatially explicit large area biomass estimation: three approaches using forest inventory and remotely sensed imagery in a GIS. Sensors 8: 529-560.

Yokkoz, N.G., Nichols, J.D. \& Boulinier, T. (2001) Monitoring of biological diversity in space and time. Trends in Ecology and Evolution 16: 446-453.

Zhao, K.G., Popescu, S. \& Nelson, R. (2009) LiDAR remote sensing of forest biomass: a scale invariant estimation approach using airborne lasers. Remote Sensing of Environment 113: 182-196. 